\title{
Rancang Bangun Sistem Informasi Kader Organisasi Forum Pemuda Pelajar Mahasiswa Tangerang (FPPMT)
}

\author{
Rohmat Taufiq ${ }^{1}$, Muhamad A'raf Iskandar ${ }^{2}$, Sofia Ashar ${ }^{3}$ \\ ${ }^{1,2}$ Teknik Informatika, University of Muhammadiyah Tangerang, Jalan Perintis Kemerdekaan I \\ Babakan No.33, RT.007/RW.003, Cikokol, Kec. Tangerang, Kota Tangerang, Banten 15118 \\ ${ }^{3}$ Teknik Informatika, Sekolah Tinggi Teknologi Muhammadiyah AR- Fachruddin Bojonegoro, \\ Sumberrejo Bojonegoro 62191
}

e-mail: 'rohmat.taufiq@umt.ac.id; ${ }^{2}$ arafiskandar122@gmail.com; ${ }^{3}$ sofiaashar@sttmarfachruddin.ac.id;

Submitted Date: March 09 ${ }^{\text {th }}, 2021$

Revised Date: June $13^{\text {th }}, 2021$
Reviewed Date: June $01^{\text {st }}, 2021$

Accepted Date: June $15^{\text {th }}, 2021$

\begin{abstract}
In an organization, of course, it cannot be separated from the term cadre or cadre. The strength of an organization is influenced by the cadres in it. If there are militant cadres who have good competence, it is certain that the organization will not experience many obstacles. Therefore, the role of cadres in the organization has a tremendous impact. This study uses interview and observation methods for the data collection process, while in the process of developing the system using the waterfall method which consists of communication with all the elements involved, planning research activities, making models with a unified modeling language (UML) and the last step is making reports. The conclusion of this research is that a Desktop-based application for the cadre data application for the Tangerang Student Youth Forum (FPPMT) has been made. The application is expected to contribute to the research organization.
\end{abstract}

Keywords: Design; Information Systems; Cadres; Organizations; Students

\begin{abstract}
Abstrak
Dalam sebuah organisasi sudah barang tentu tidak akan lepas dari istilah pengkaderan atau kaderisasi. Kuat tidaknya sebuah organisasi salah satunya dipengaruhi oleh kader-kader yang ada didalamnya. Jika terdapat kader-kader militant dan yang memiliki kompetensi yang bagus maka sudah pasti oranisasi tersebut tidak mengalami banyak hambatan. Maka dari itu peran kader dalam organisasi memiliki dampak yang luar biasa. Penelitian ini menggunakan metode wawancara dan observasi guna proses pengumpulan data sedangkan dalam proses pengembangan sistem menggunakan metode waterfall yang terdiri dari komunikasi dengan semua unsur yang terlibat, pembuatan perencanaan kegiatan penelitian, pembuatan model dengan unified modelling language (UML) dan langkah yang terakhir pembuatan laporan. Kesimpulan dari penelitian ini sudah dibuat sebuah aplikasi data kader organisasi forum pemuda mahasiswa tangerarang (FPPMT) berbasis Desktop. Aplikasi tersebut diharapkan bisa memberikan kontribusi buat organsisasi tempat penelitian.
\end{abstract}

Kata kunci: Rancang Bangun; Sistem Informasi; Kader; Organisasi; Mahasiswa

\section{Latar Belakang}

Pada zaman modern seperti sekarang ini tidak bisa dipungkiri bahawasanya semua diharapkan bisa real time, akurat dan tepat. Untuk mencapai hal tersebut sulit didapatkan tanpa adanya bantuan teknologi informasi yang canggih. Teknologi informasi dijadikan sebagai sastu- satunya pilihan karena di dalamnya sudah lengkap terdapat komputer dan alat komunikasi. Bagi sebuah organisasi sangat memungkinkan menggunakan teknologi informasi khususnya teknologi informasi berbasis web, karena data dan informasi yang disampaikan melalui website dapat diakses dengan mudah dan tersebar lebih cepat 
sehingga lebih efisien (Yulianti, Saifudin, Haryono, Zulfikar \& Desyani, 2020).

Dengan perkembangan teknologi informasi maka sudah dipastikan bahawanya semuanya akan berjalan lebih efisien dan efektif serta memiliki akurasi yang tinggi.

Forum Pemuda Pelajar Mahasiswa Tangerang (FPPMT) adalah salah satu organisasi ekstrak kampus yang bergerak di bidang politik, pendidikan, lingkungan, kesehatan, yang berada di wilayah Kabupaten Tangerang. Mengingat semakin meningkatnya jumlah pendidikan dan kesehatan di Forum Pemuda Pelajar Mahasiswa Tangerang (FPPMT).

Serta makin meningkat pula proses penginputan data dalam suatu peroses kader forum untuk mengurangi kesalahan dalam penginputan data kader tersebut, Forum Pemuda Pelajar Mahasiswa Tangerang (FPPMT) masih melakukan pengolahan data kader. Penelitian tersebut diharapkan memberikan dampak yang positif bagi organisasi tersebut.

\section{Landasan Teori}

\subsection{Rancang Bangun}

Rancang bangun merupakan kumpulan kegiatan yang mengisyaratkan atau menjelaskan sistem yang berjalan secara detail (Satzinger, Jakson dan Burd, 2012). Hasil dari analisis yang selanjutnya direkomendasikan untuk proses pengembangan itulah yang disebut dengan perancangan (Subhan, 2012). IEEE telah mendefinisikan bahwa pengebangan software merupakan suatu rumusan sistematis, terstruktur serta terukur untuk perancangan, pengukuran serta maintenance software (Pressman dan Maxim, 2015).

Beberapa faktor-faktor kegagalan sistem disebabkan oleh perencanaan, sponsor, desain, komunikasi, disiplin dan pemasok (Tantra, 2012). Sebuah proses pengembangan sebaiknya dilakukan analisis agar dapat memberikan kemudahan pada saat proses pengembangan berjalan (Pertiwi dan Taufiq, 2020). Hasil dari analisis selanjutnya dilakukan perancangan berbasis web (Taufiq dkk, 2020).

\subsection{Sistem Informasi}

Tujuan tertentu dari sebuah organisasi akan dicapai dengan saling berhubungan dan bekerja sama antara sub sub sistem yang ada didalam organisasi tersebut (Taufiq dkk, 2020). Kumpulan komponen yang saling berhubungan dengan era tantara satu dengan yang lainnya dengan tujuan untuk mencapai tujuan yang sama itulah yang disebut dengan sistem (Sutabri, 2012). Saling berhubungan dari satu atau beberapa sub sistem dengan satu tujuan yang sama juga disebut dengan sistem (Romney dan Steninbart, 2014). Beberapa sub sistem yang berkumpul dan saling berhubungan serta melakukan kerjasama dengan tujuan menyelesaikan kasus tertentu dengan metode mengolah data yang nantinya akan memiliki nilai tambah dan memiliki manfaat bagi user itulah yang disebut dengan sistem informasi (Taufiq, 2018).

\subsection{Kader Organisasi}

Sebuah organisasi yang ada dalam lingkungan masyarakat membutuhkan kader yang baik, memiliki pemikiran yang maju, kepribadian dan perilaku yang sopan santun maka diperlukan sebuah proses pengkaderan yang tepat dan baik (Waluyo, 2011). Proses kaderisasi ini sangat diperlukan dalam organisasi karena semua sumber daya manusia yang ada pasti suatu saat membutuhkan pengganti karena faktor usia dan lain sebagainya (Rivai, 2014).

\subsection{Mahasiswa}

Orang yang belajar guna mencari ilmu serta terdaftar secara resmi untuk menjelani Pendidikan yang berada dalam perguruan tinggi baik itu universitas, institute, sekolah tinggi, politeknik serta akademik. Orang tersebut bisa disebut sebagai mahasiswa karena sudah diakui oleh unviersitas ataupun Lembaga Pendidikan tinggi (Hartaji, 2012). Dalam KBI orang yang belajar di tingkat universitas disebut sebagai mahasiswa (Kamus Bahasa Indonesia Online, kbbi.web.id)

\section{Metode Penelitian}

Dalam metode penelitian ada 2 tahap yang dilakukan yaitu metode pencarian data dan metode perancangan sistem. Untuk memperoleh data yang benar maka kegiatan yang dilakukan wawancara dengan semua pihak, melihat langsung di tempat penelitian serta mempelajari jurnal atau buku yang sudah ada. 


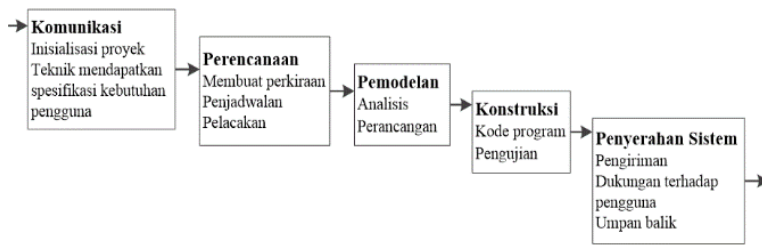

Gambar 1. Metode Pengembangan Sistem

Sedangkan metode perancangan sistem yaitu dengan waterfall. Metode waterfall masuk di dalam golongan system development life cycle (SDLC) yang menunjukkan pada pola sistematis serta runtut dalam proses perancangan sebuah aplikasi berbasis komputer, langkah yang dilakukan dalam waterfall diawali dengan komunikasi dengan seluruh yang terlibat dalam penggunaan sistem ataupun komunikasi dengan orang yang mendanai sistem tersebut untuk menginisiasi proyek serta spesifikasi yang dibutuhkan oleh pengguna.

Langkah kedua yaitu membuat perencanaan mengenai software atau hardware yang digunakan serta waktu yang akan diperlukan untuk menyelesaikan. Selanjutnya pemodelan dilakukan untuk menggambarkan model sebelum dilakukan perancangan. Langkah yang keempat yaitu konstruksi atau proses pembuatan program aplikasi serta dalam langkah ini diperlukan juga pengujian. Pengujian aplikasi memiliki peranan penting dalam suatu pengembangan sistem karena bertujuan untuk menemukan Galat atau Error yang akan muncul pada sistem dan memperbaiki (Ahrizal, Miftah, Kurniawan, Zaelani, \& Yulianti, 2020). Pengujian sistem bertujuan untuk memastikan bahwa semua proses sudah berfungsi sesuai dengan kebutuhan yang ditetapkan (Muslimin, et al., 2020).

Langkah yang terakhir yaitu penyerahan sistem, langkah ini mejelaskan kapan pengiriman sistem, kebutuhan buat user untuk menggunakan software yang sudah dikirim serta melihat umpan balik dari pengguna.

\section{Analisis dan Perancangan}

\subsection{Sistem yang berjalan}

Sistem pengolah data yang berjalan masih menggunakan sistem manual sehingga membutuhkan sistem berbasis web atau desktop untuk meningkatkan kinerja pada Sistem Infomasi data kader berbasis Dekstop pada FPPMT (Forum Pemuda Pelajar Mahasiswa Tangerang) yang dibuat.

Gambar flowchart yang tertera pada Gambar 2 di atas menjelaskan bagaimana seorang user melakukan login pada sistem yang akan dirancang. Masing-masing pengguna memiliki user name dan password yang berbeda-beda serta menu dan laporan yang berbeda juga.

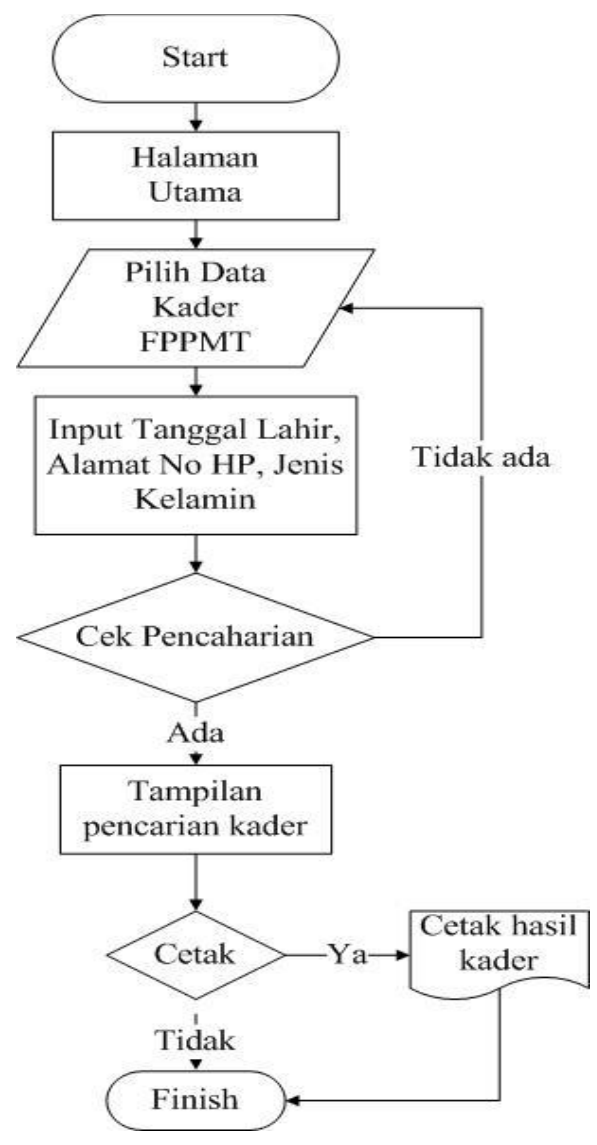

Gambar 2. Sistem yang berjalan

\subsection{Pembuatan Desain Use Cases}

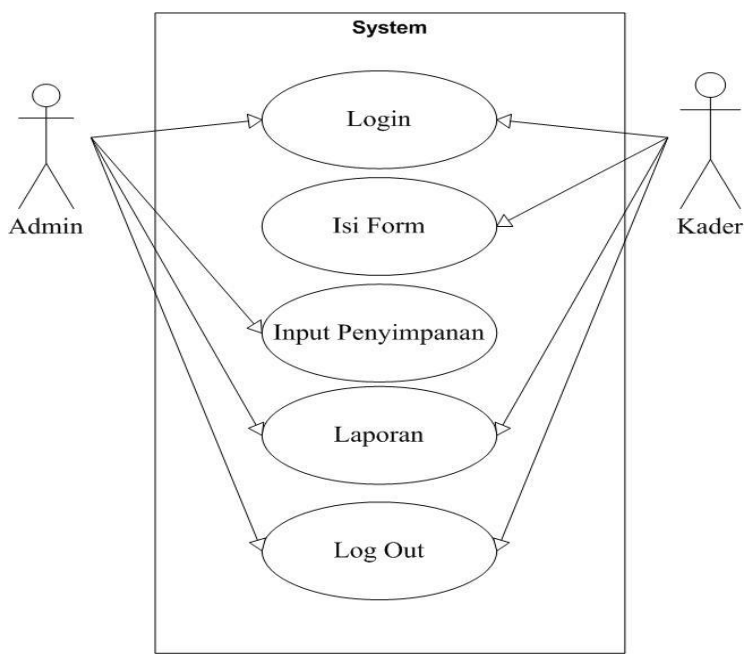

Gambar 3 Use Case 
Gambar 3 tentang use case tersebut menjelaskan bagaimana seorang aktor berhubungan dengan sistem. Dalam use case tersebut terdapat 2 aktor dimana masing-masing aktor memiliki hak akses yang berbeda-beda.

\section{Activity Diagram}

Dalam activity diagram terdapat beberapa activity, namun yang tampilkan pada jurnal ini ini activity diagram input penyimpanan.

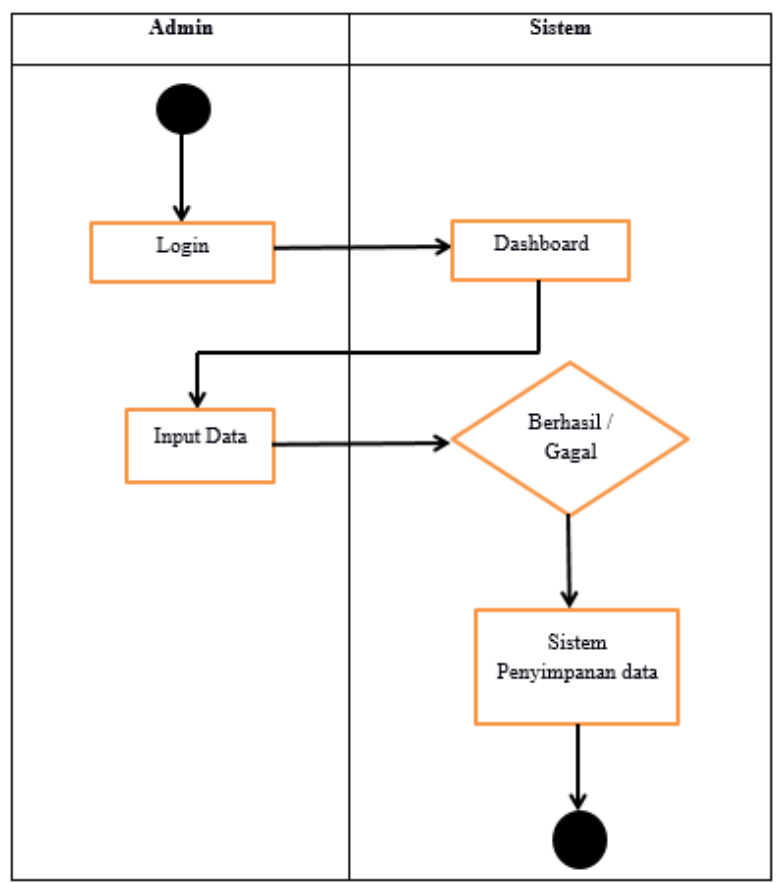

Gambar 4 Activity Diagram penyimpanan

Proses penyimpanan data kader yang dilakukan oleh pengguna ditampilkan dalam gambar 4 diatas. Sebelum melakkukan input data kader langkah awal yang dilakukan yaitu login selanjutnya masuk ke dashboard lalu input data dan penyimpanan data dilakukan.

\section{StateChart Diagram}

Statechart diagram menjelaskan seorang user melakukan kegiatannya dengan sistem yang dibuat. Langkah awal user melakukan pilih nama dan jenis kelamin lalau akan muncul tampilkan data kader selanjutnya melakukan input data kegiatan kader tersebut lalu langkah terakhirnya adalah menyimpan kegiatan yang sudah diinput tersebut.

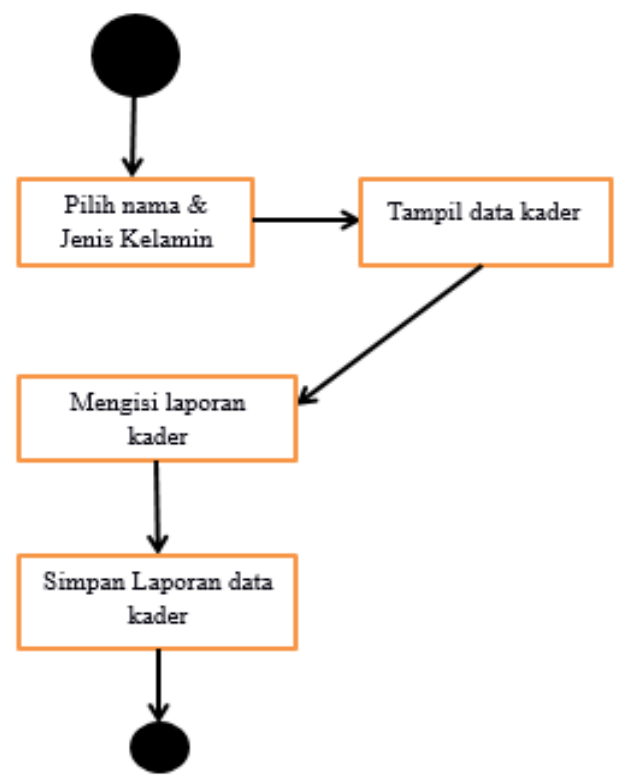

Gambar 5 Statechart diagram Laporan

\section{Sequence Diagram}

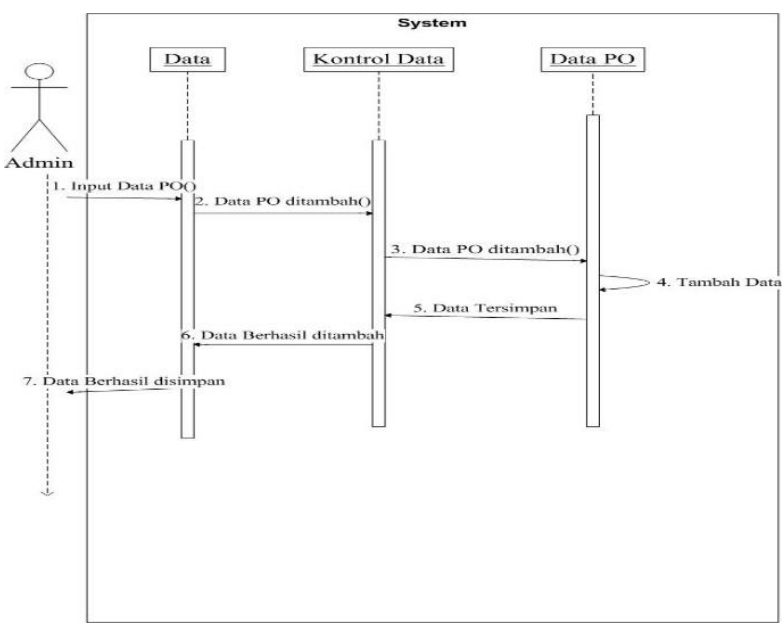

Gambar 6 Sequence Diagram penyimpanan

Gambar 6 diatas menjelaskan bagaimana seorang user memasukkan data dalam proses penyimpanan data kader yang akan dimasukkan. Admin input data kader selanjutnya control data dan yang terakhir proses penyimpanan data yang sudah dimasukkan tadi.

\section{Desain}

Gambar 7 tentang data kader diatas mengasumsikan bahwa sistem yang dibangun nanti bisa digunakan untuk menyimpan data kader berpa field nama, alamat, no telp dan jenis kelamin. Selain itu bisa digunakan untuk tambah, simpan, edit, hapus dan keluar. 


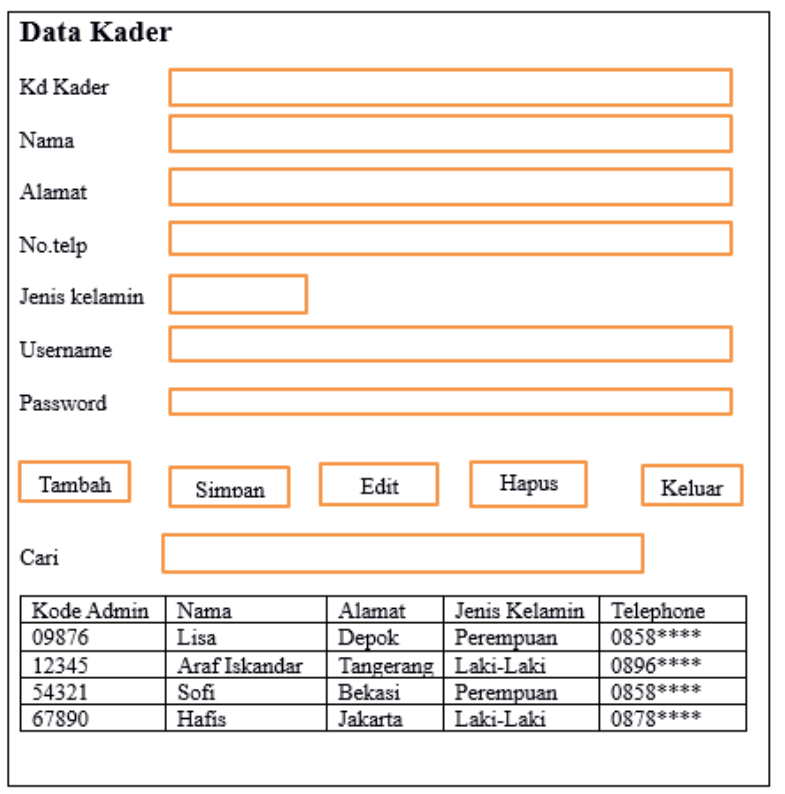

Gambar 7 Data Kader

\subsection{Implementasi Form login}

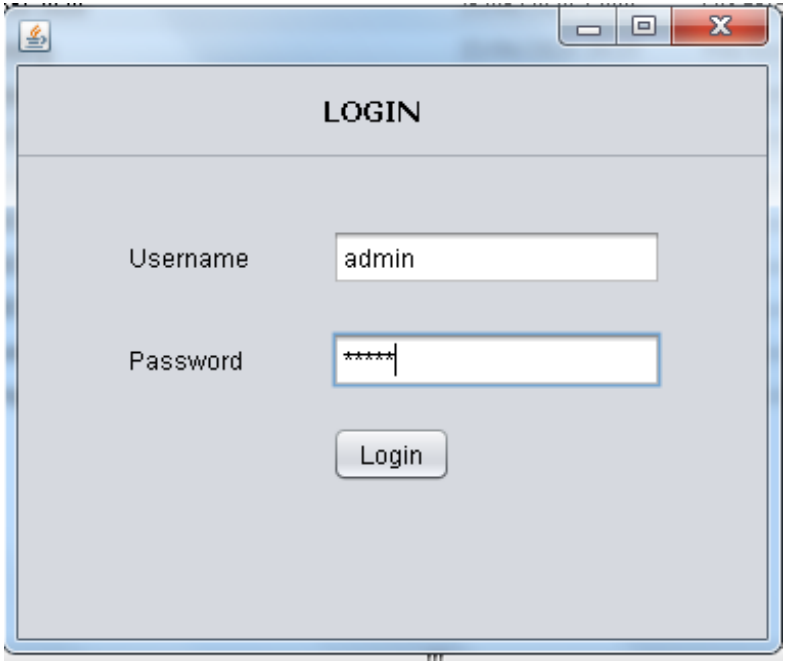

Gambar 8 Form Login

Form login yang tertera pada gambar 8 diatas menjelaskan bagaimana seorang aktor atau user bisa masuk ke sistem melalui login tersebut. Terdapat 2 jenis user yang bisa login dalam sistem ini.

\section{Form Tambah Data Kader}

Ada beberapa field yang bisa dimasukkan dalam form tambah data kader yang tertera pada Gambar 8. Field tersebut terdiri dari kode kader, nama, alamat, no telp, jenis kelamin, user name dan password. Form ini berfungsi untuk melakukan tambah kader, simpan, edit, hapus dan keluar dari aplikasinya.

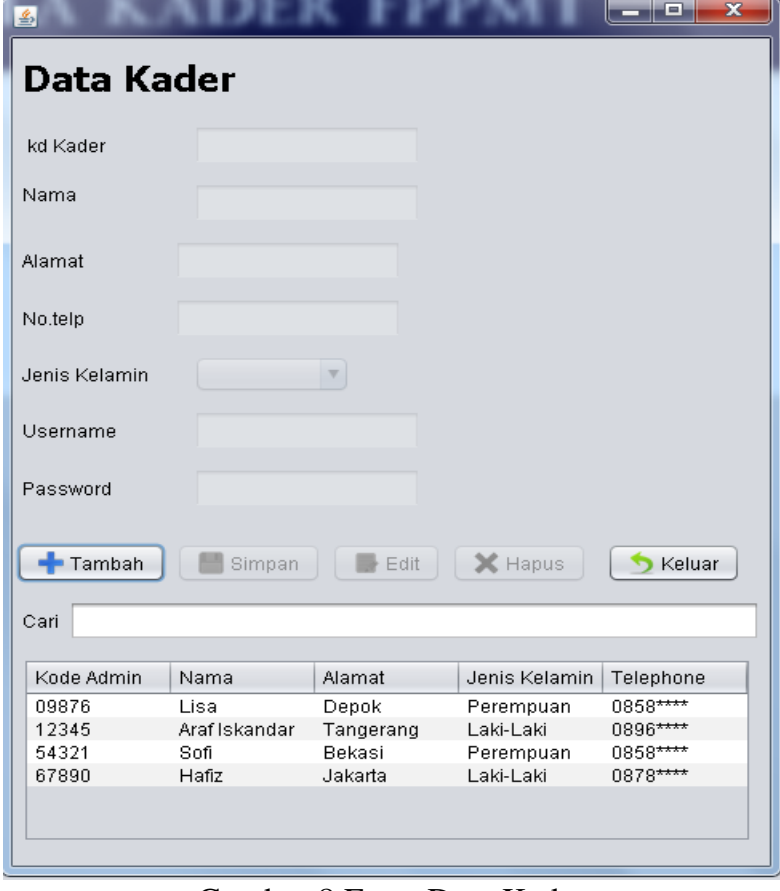

Gambar 8 Form Data Kader

\section{Kesimpulan}

Terdapat 2 kesimpulan dari penelitian tetang data kader di organisasi FPPMT (Forum Pemuda Pelajar Mahasiswa Tangerang) adalah:

1. Analisis dan desain digunakan untuk memudahkan dalam proses perancangang sistem sehingga sangat membantu bagi peneliti untuk memeberikan akurasi data yang tepat sehingga sesuai dengan kebutuhan.

2. Aplikasi yang sudah dibuat sudah dilakukan uji coba, dalam proses pengujian menyebutkan bahwasanya aplikasi yang sudah dikembangkan sesuai dengan kebutuhan forum pemuda pelajar mahasiswa tangerang. Aplikasi ini sangat membantu dalam mengamankan data dan memudahkan untuk melihat laporan yang ada.

\section{Referensi}

Ahrizal, D., Miftah, M. K., Kurniawan, R., Zaelani, T., \& Yulianti, Y. (2020). Pengujian Perangkat Lunak Sistem Informasi Peminjaman PlayStation dengan Teknik Boundary Value Analysis Menggunakan Metode Black Box Testing. Jurnal Informatika Universitas Pamulang, $\quad$ 5(1), 73-77. doi:10.32493/informatika.v5i1.4338

Hartaji, Damar A. (2012). Motivasi Berprestasi Pada Mahasiswa yang Berkuliah Dengan Jurusan Pilihan Orangtua. Fakultas Psikologi Universitas Gunadarma. 
KBBI, 2016. Kamus Besar Bahasa Indonesia (KBBI). [Online] Available at: http://kbbi.web.id/, [Diakses September 2020]

Muslimin, D. B., Kusmanto, D., Amilia, K. F., Ariffin, M. S., Mardiana, S., \& Yulianti, Y. (2020). Pengujian Black Box pada Aplikasi Sistem Informasi Akademik Menggunakan Teknik Equivalence Partitioning. Jurnal Informatika Universitas Pamulang, 5(1), 19-25. doi:10.32493/informatika.v5i1.3778

Pertiwi, D.D and Taufiq, R. 2020. “Analisis dan Desain Sistem Informasi Pengolahan Nilai Siswa di SMK Avicena Rajeg”, J. Tek. Inform. Univ. Muhammadiyah Tangerang. ISSN: 2549-0710.

Pressman, RS dan Maxim, BR (2015) Software Engineering a Practitioner's Approach $\left(8^{\text {th }}\right.$ edition). Mc Graw-Hill.

Rivai, V (2014). Manajemen Sumber Daya Manusia untuk Perusahaan, Edisi ke 6, PT. Raja Grafindo Persada, Depok, 16956.

Romney, Marshall B. dan Steinbart, Paul John, (2009), "Accounting Information System". Cengage Learning, USA.

Satzinger, JW., Jackson, RB dan Burd, SD (2012). Systems Analysis and Design in a Changing World. Cengage Learning. USA.

Subhan, M (2012). Analisa Perancangan Sistem. Jakarta. Lentera Ilmu Cendikia.

Sutabri, T (2012). Analisis Sistem Informasi. Andi. Yogyakarta.

Tafiq, R. Muttaqijn, MI. Mukhofa, MI dan Effendi, Y (2020). Sistem Informasi Manajemen. Edisi 2. Graha Ilmu. Yogyakarta.

Tantra. R (2012). Manajemen Proyek Sistem Informasi. Andi. Yogyakarta.

Taufiq, R. (2018) "Pengantar Sistem Informasi". Jakarta. Mitra Wacana Media.

Taufiq, R., Sulkhan., Yulianti dan Saifudin, A (2020). Analisis dan Desain Sistem Pendukung Keputusan Penilaian Kinerja Pegawai dengan Metode Analytical Hierarchy Process (AHP). Jurnal Informatika Universitas Pamulang. Vol. 5, No. 3. September 2020 (307-314).

Waluyo, A (2011). Indonesian Nurses'HIV Knowledge, Religiosity, Individual Stigma Attitudes, and Workplace HIV-Stigma. University of Illinois at Chicago, 2011. waluyo_agung.pdf.

Yulianti, Y., Saifudin, A., Haryono, W., Zulfikar, A. F., \& Desyani, T. (2020). Pengembangan dan Sosialisasi Website untuk Meningkatkan Penyebaran Informasi SMP Islam Madinatul I'lmi Ciputat-Tangerang Selatan. KOMMAS: Jurnal Pengabdian Kepada Masyarakat, 1(1), 16-24. 